\title{
Analisis Tata Ruang dan Makna Simbolis Ragam Hias Binatang pada Klenteng Tulus Harapan Kita (Thian Huo Kiong) Gorontalo
}

\author{
Tresiyani Mettasari Liesawan ${ }^{1}$, Jesseline Carissa Novita ${ }^{2}$ \\ ${ }^{1,2}$ Mahasiswa Desain Interior Universitas Kristen Petra Surabaya \\ ${ }^{1}$ treslie001@gmail.com, ${ }^{2}$ jesseline.cn@ gmail.com
}

\begin{abstract}
ABSTRAK
Klenteng adalah tempat ibadah Tionghoa yang identik dengan warna merah pada bangunannya. Tak hanya warna, klenteng juga memiliki pembagian ruang khusus untuk altar sembahyang yang biasanya terbagi dalam beberapa area. Masing-masing area memiliki keunikan tersendiri yang menarik untuk dianalisa interiornya. Di Klenteng Tulus Harapan Kita (Thian Huo Kiong) Gorontalo terdapat beberapa ragam hias makhluk hidup yang diterapkan pada interior baik berupa lukisan maupun ukiran di dinding. Ragam hias makhluk hidup yang paling sering dijumpai pada klenteng ini adalah naga dan singa dimana elemen-elemen ini memiliki makna simbolis masing-masing. Tujuan dari penelitian ini adalah untuk mengetahui pembagian tata ruang dalam interior Klenteng Tulus Harapan Kita (Thian Huo Kiong) Gorontalo dan makna simbolis dari ragam hias binatang yang terdapat di dalam klenteng. Penelitian ini akan menggunakan metode kualitatif dengan pendekatan deskriptif dan pengumpulan data akan dilakukan dengan dua cara yakni teknik observasi dan studi literatur.
\end{abstract}

Kata kunci: klenteng; tata ruang; makna simbolis; makhluk hidup

\section{ABSTRACT}

Temple is a Chinese place of worship that identical to the red color on the building. Not only color, but the temple also has a special space division for altar worship that is usually divided into several areas. Each area has its own uniqueness that is interesting to analyze the interior. In addition, in the Tulus Harapan Kita (Thian Huo Kiong) temple there are several animal elements applied to the interior both in the form of paintings and carvings on the walls. The most common elements found in this temple are dragons and lions that each symbol has its own meaning. The purpose of this research is to know the division of spatial layout in the interior of Tulus Harapan Kita (Thian Huo Kiong) Gorontalo and the symbolic meaning of the variety of animal ornaments contained in the temple. This research will use a qualitative method with a descriptive approach and data collection will be done with observation and literature studies.

Keywords : temple; layout; symbolic meanings; animals

\section{PENDAHULUAN}

Indonesia memiliki banyak keberagaman di antaranya ras, budaya, suku bangsa, kepercayaan, bahasa hingga agama. Keberagaman yang ada di Indonesia menjadikan Indonesia sebagai salah satu negara yang kaya dan sebagai satu kesatuan dengan ikatan persaudaraan bangsa yang tinggi antar masyarakat. Indonesia merupakan negara beragama yang mengakui enam agama yakni Islam, Katolik, Kristen, Hindu, Budha dan Konghucu. Masyarakat diberikan hak dan kebebasan untuk memilih agama apa yang ingin dianut. Setiap agama memiliki kepercayaan dan aturan tersendiri dalam beribadah. Perbedaan kepercayaan dan aturan serta tradisi yang dimiliki tiap agama membuat masyarakat lebih mengembangkan sifat toleransi ke sesama.

Etnis Tionghoa yang datang ke Indonesia sebagian besar berasal dari suku Hokkian, Tiochiu, Kanton, Hakka dan Hainan. Indonesia adalah negara dengan populasi etnis Tionghoa terbesar di dunia yang tinggal di luar Cina. Sekitar 7,6 juta jiwa etnis Tionghoa bermukim di Indonesia (Katadata, Desember 13, 2016). Ditinjau dari aspek sejarah, kedatangan etnis 
Tresiyani Mettasari Liesawan ${ }^{1}$, Jesseline Carissa Novita ${ }^{2}$

Analisis Tata Ruang dan Makna Simbolis Ragam Hias Binatang pada Klenteng Tulus Harapan Kita (Thian Huo Kiong) Gorontalo

Tionghoa ke Gorontalo tidak diketahui asal usulnya dengan pasti. Namun beberapa kalangan masyarakat percaya bahwa etnis Tionghoa masuk ke Gorontalo melalui Manado. Etnis Tionghoa ini tertarik untuk menetap di Gorontalo karena saat itu Gorontalo termasuk daerah pusat perekonomian (Hasanuddin, \& Basri Amin, 2013). Kelompok Tionghoa ini memilih untuk tetap mempertahankan kepercayaan religi dan tradisi kebudayaan mereka yang mereka bawa dari asal sebelumnya. Untuk wilayah Gorontalo, kepercayaan yang tetap dipertahankan hingga masa sekarang adalah Budhisme dan Taoisme.

Etnis Tionghoa pernah mengalami diskriminasi pendidikan dan budaya pada masa orde baru dimana saat itu adalah masa pemerintahan Presiden Soeharto. Adanya larangan kepada etnis Tionghoa untuk melakukan aktivitas seperti merayakan hari besar, menyanyikan lagu Tionghoa, hingga menghentikan pembelajaran budaya Tionghoa dengan menutup sekolah Tionghoa di Indonesia. Tentu saja hal ini mengakibatkan penguasaan bahasa khususnya bahasa Mandarin menurun. Pelarangan dari presiden ini berimbas tidak hanya ke masyarakat Gorontalo namun juga ikut berimbas pada masyarakat keturunan Tionghoa di Indonesia. Saat itu masyarakat maupun pemerintah sangat kesulitan untuk mencari dan mengakses data mengenai adat, budaya hingga tradisi Tionghoa (Liang Liji,2012:516).

Makna diartikan sebagai maksud yang terkandung. Makna dapat meliputi simbol, suatu kebiasaan, isyarat maupun kepercayaan. Menurut Kamus Besar Bahasa Indonesia, makna ialah memperhatikan setiap kata, maksud pembicaraan yang ingin disampaikan atau ditimbulkan dan merupakan pengertian yang diberikan pada suatu bentuk kebahasaan. Ornamen adalah hal yang sering muncul dalam sebuah klenteng. Ornamen merupakan bentuk karya seni yang digunakan sebagai penghias atau penambah nilai estetika suatu benda. Ornamen memiliki nilai simbolik tertentu yang berhubungan dengan pandangan hidup manusia. Makna yang terkandung dalam sebuah ornamen klenteng selalu berhubungan dengan kehidupan manusia. Terdapat tiga faktor yang mempengaruhi makna ornamen pada klenteng yakni ornamen sebagai seni dalam kebudayaan, ornamen sebagai simbol religi, dan yang terakhir adalah ornamen sebagai ideologi yang biasanya berkaitan dengan hal-hal yang bersifat mitos atau diluar pikiran manusia (Polniwati Salim, 2011).

Klenteng dalam Kamus Besar Bahasa Indonesia diartikan sebagai bangunan tempat berdoa atau bersembahyang dan melakukan upacara keagamaan namun memiliki arti lain sebagai tiruan bunyi lonceng. Istilah klenteng hanya terdapat di Indonesia, di negara Cina tempat ibadah ini tidak disebut sebagai klenteng. Di Indonesia, klenteng merupakan sarana pemersatu warga Tionghoa. Di dalam sebuah klenteng terdapat altar untuk sembahyang dengan tata ruang berbeda-beda ditiap klenteng. Tata ruang pada masing-masing klenteng ini memiliki maksud dan tujuan tertentu begitu juga dengan ornamen pengisi ruangnya. Tata letak klenteng dapat mempengaruhi aktivitas umat yang beribadah didalamnya. Selain memiliki penataan ruang yang berbeda, dalam klenteng juga memiliki banyak ragam hias berupa elemen maupun simbol yang tidak hanya dijadikan sebagai pengisi ruang atau estetika melainkan memiliki makna tersendiri. Kleteng Tulus Harapan Kita (Thian Huo Kiong) adalah satu-satunya klenteng yang ada di kota Gorontalo yang sudah berdiri sejak tahun 1827 . Klenteng ini menjadi pusat ibadah untuk menjalankan tradisi maupun acara adat lainnya saat hari penting. Pengurus dan pengguna klenteng terdahulu adalah para sesepuh yang tahu semua arti dan makna ragam hias yang ada di klenteng, misalnya simbol naga memiliki arti kekuatan dan tenaga dari dewa (Polniwati Salim, 2011). Namun sangat disayangkan generasi muda sekarang minim rasa ingin tahu mengenai hal itu.

Oleh karena itu, penelitian ini dilakukan untuk menganalisis pembagian tata ruang beserta makna simbolis dari ragam hias khususnya binatang yang berada di Klenteng Tulus Harapan Kita (Thian Huo Kiong) di Gorontalo. Penelitian ini diharapkan agar generasi muda 
dapat mengetahui pembagian area klenteng dengan lebih detail dan bisa memahami makna simbolis dari elemen yang ada di dalam klenteng.

\section{METODE PENELITIAN}

Penelitian ini akan dilakukan dengan pendekatan pada kondisi objektif yang alamiah atau biasa disebut dengan metode kualitatif dan akan menggunakan pendekatan deskriptif. Metode pendekatan deskriptif adalah metode yang digunakan untuk mencari unsur, ciri maupun sifat dari suatu fenomena dimana akan dilakukan Analisa pembagian tata ruang serta mengidentifikasi jenis dan makna simbolis dari ragam hias binatang yang ada di Klenteng Tulus Harapan Kita (Thian Huo Kiong).

\section{A. Lokasi Penelitian}

Penelitian ini akan dilaksanakan di Klenteng Tulus Harapan Kita (Thian Huo Kiong) yang berada di Jalan S.Parman, Kelurahan Biawao, Kecamatan Kota Selatan, Kota Gorontalo. Hal yang akan diteliti adalah berfokus pada penataan ruang untuk altar sembahyang, dekorasi klenteng, ragam hias binatang yang ada di klenteng, kolom, pintu dan atap bangunan.

\section{B. Metode Pengumpulan Data}

Penelitian mengenai tata ruang dan makna simbolis dari ragam hias binatang di Klenteng Tulus Harapan Kita Gorontalo menggunakan dua metode pengumpulan data di antaranya:

\section{Teknik Observasi}

Akan melakukan observasi langsung di Klenteng Tulus Harapan Kita (Thian Huo Kiong) Gorontalo dan mengambil dokumentasi berupa foto dari kamera digital dan menghimpun data (Suwartono, 2014: 42). Yang akan diobservasi dalam penelitian ini berkaitan dengan tata ruang dan ragam hias yang ada di klenteng.

\section{Studi Literatur}

Metode pengumpulan data yang kedua adalah studi literatur. Pada metode ini akan dilakukan dengan mencari data serta informasi yang berasal dari buku, jurnal, maupun tesis yang berkaitan dengan topik penelitian.

\section{HASIL PENELITIAN DAN PEMBAHASAN}

\section{A. Pengertian Klenteng}

Klenteng merupakan sebuah tempat suci untuk melakukan ibadah bagi pemeluknya. Di dalam klenteng terdapat banyak tradisi serta upacara keagamaan yang sering dilakukan di tanggal tertentu. Sebagai tempat ibadah, klenteng memiliki arca dewa dan dewi dari aliran Tri Dharma yakni Taoisme, Konfusianisme dan Budhisme. Banyak ajaran moral yang dapat dipelajari oleh umat dari para dewa dan dewi ini karena sebagian besar dari para dewa ini adalah manusia biasa yang memiliki kesucian jiwa, perbuatan baik maupun kemampuan di bidang tertentu yang kemudian dihormati dan diangkat menjadi dewa atau dewi. Nilai luhur dan sifat baik yang mulia inilah yang dapat dipetik dan dipelajari oleh etnis Tionghoa saat beribadah atau berkunjung ke sebuah klenteng.

Dalam pembangunan klenteng, biasanya ada dewa atau dewi utama yang sekaligus menjadi sejarah acuan masyarakat Tionghoa di satu daerah. Misalnya saja jika Dewi Laut yang menjadi dewi utama pada sebuah klenteng, maka diperkirakan bahwa masyarakat Tionghoa di daerah itu mayoritas adalah pedagang maupun nelayan. Atau jika Dewa Bumi yang menjadi dewa utama, maka kemungkinan besar saat itu masyarakat Tionghoa di daerah itu mayoritas adalah petani. Dalam beberapa kasus pembangunan sebuah klenteng, penentuan dewa atau dewi utama mendapat cerminan dari marga dominan masyarakat di sekitar klenteng 
Tresiyani Mettasari Liesawan ${ }^{1}$, Jesseline Carissa Novita ${ }^{2}$

Analisis Tata Ruang dan Makna Simbolis Ragam Hias Binatang pada Klenteng Tulus Harapan Kita (Thian Huo Kiong) Gorontalo

itu akan dibangun. Ada juga beberapa marga tertentu yang membangun klenteng khusus untuk marganya dan menjadikan dewa atau dewi yang berasal dari marganya menjadi dewa atau dewi utama di klenteng.

Klenteng Tulus Harapan Kita (Thian Huo Kiong) Gorontalo adalah kelenteng yang sudah berdiri selama 194 tahun dan masih terorganisir dengan baik. Klenteng ini sudah beberapa kali melakukan renovasi untuk memperbaiki maupun mengubah desain klenteng menjadi lebih baik. Setelah renovasi terakhir dilakukan, klenteng ini menghilangkan beberapa bagian interior yang sedikit kuno. Desain klenteng juga tidak dipenuhi dengan warna merah pada seluruh ruangan. Selain itu, material yang digunakan juga terkesan lebih modern. Klenteng Tulus Harapan Kita (Thian Huo Kiong) sekarang terdiri dari 3 lantai. Setiap lantai nya memiliki area sembayang sendiri dengan altar khusus yang disediakan untuk masing-masing dewa.

\section{B. Tata Ruang Pada Klenteng Tulus Harapan Kita}

Klenteng Tulus Harapan Kita (Thian Huo Kiong) Gorontalo ini memiliki total 5 area sembahyang dengan 2 yang terletak di lantai 1,2 dan 3. Pada masing-masing area terdapat altar sembahyang yang beragam. Untuk membantu umat yang beribadah, setiap altar sembahyang diberikan tanda pengenal berupa papan kayu yang bertuliskan nama dari dewa di altar tersebut.
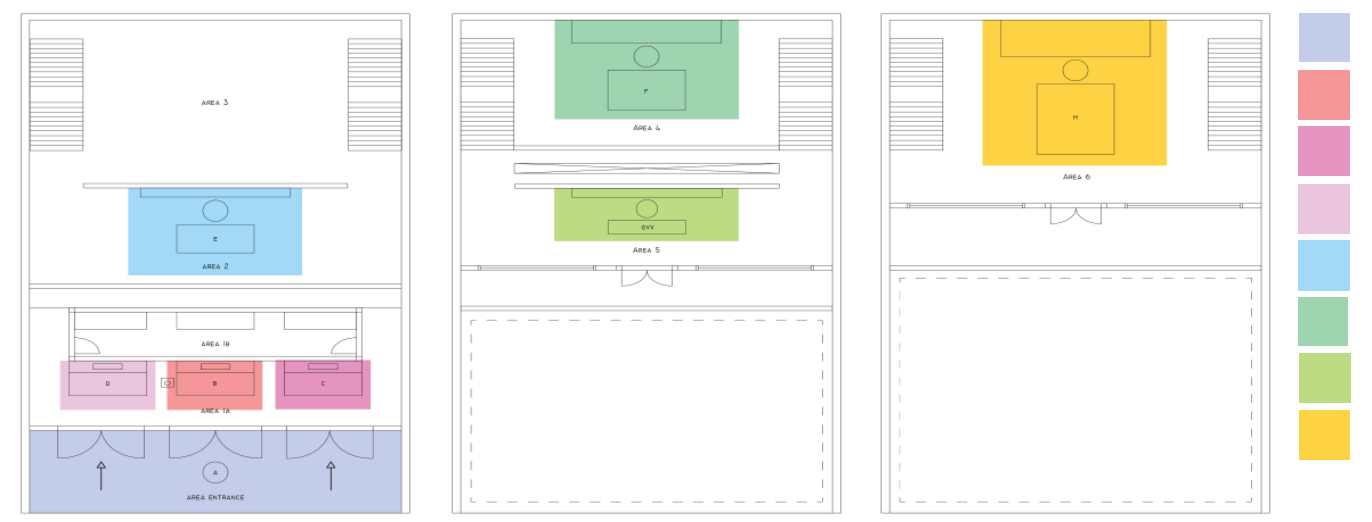

Area Masuk

Altar 1

Altar 2

Altar 3

Altar 4

Gambar 1. Tata Ruang Klenteng Tulus Harapan Kita (Dari kiri lantai 1 - lantai 3) Sumber : Dokumentasi Penulis (2021)
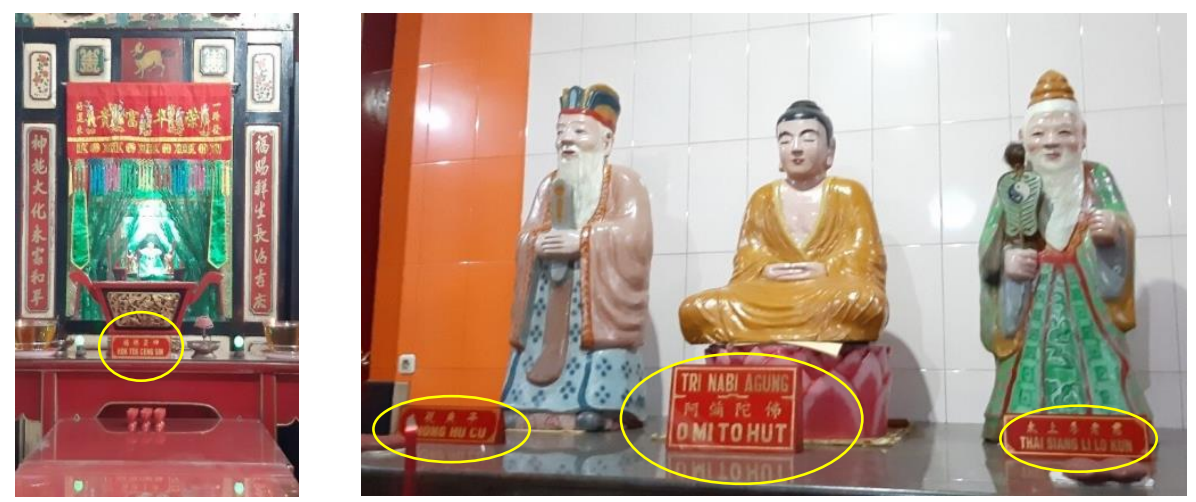

Gambar 2. Papan Pengenal di Setiap Altar Sembahyang Sumber : Dokumentasi Penulis (2021) 


\section{Area Masuk}

Pada Area masuk terdapat 3 pintu besar yang berjejer. Pintu tengah adalah pintu tuan rumah (dewa utama), pintu kanan disebut pintu harimau dan pintu kiri disebut pintu naga. (Damayanti, 2017). Pintu Klenteng Tulus Harapan Kita (Thian Huo Kiong) dilengkapi dengan ornamen khas Cina yakni lukisan naga pada daun pintu dan ukiran pada dinding di samping pintu yang memiliki makna sebagai penangkal roh jahat.

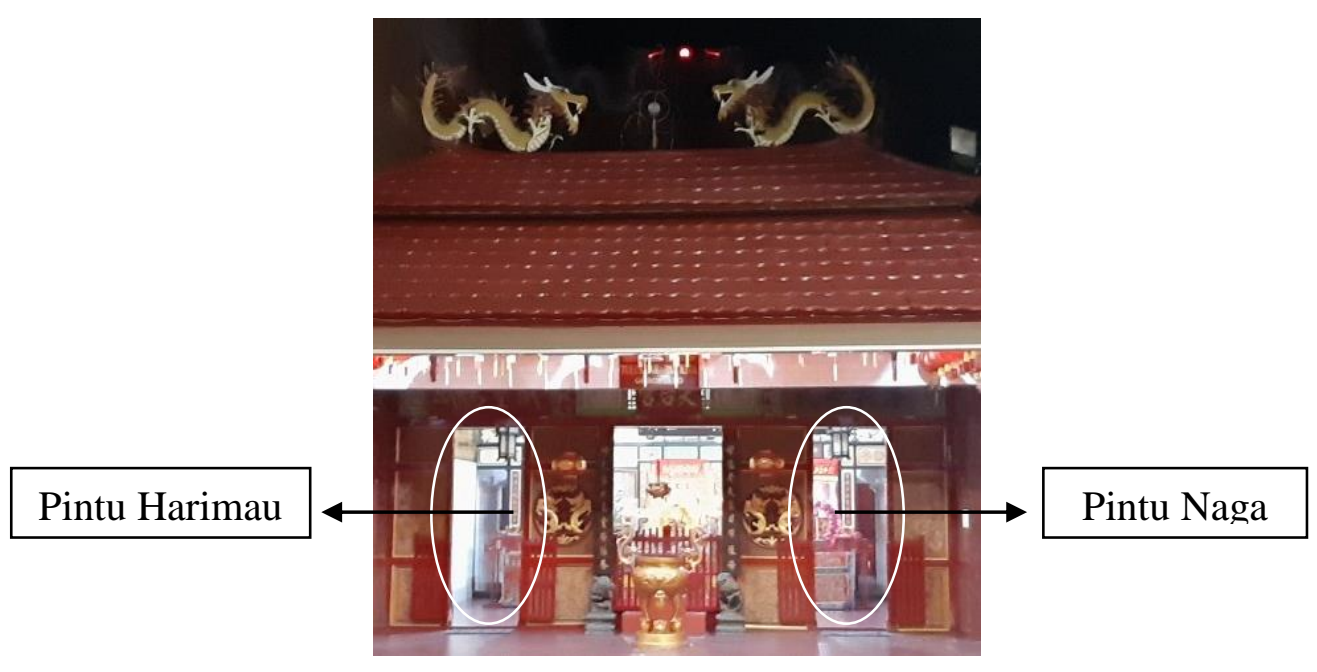

Gambar 3. Area Masuk Klenteng Sumber : Dokumentasi Penulis (2021)

Pintu masuk Klenteng Tulus Harapan Kita ini berwarna merah dan memiliki pagar kecil yang juga berwarna merah di setiap pintu. Pagar merah untuk pintu naga dan harimau selalu terbuka untuk sirkulasi masuk dan keluar klenteng (Pintu Naga sebagai pintu masuk, Pintu Harimau sebagai pintu keluar) namun pagar pada pintu tengah hanya dibuka saat ada perayaan khusus atau sembahyang besar saja seperti imlek.

\section{Lantai 1}

Penempatan altar sembahyang di klenteng ini terbagi menjadi beberapa altar. Untuk lantai 1 terdapat 4 altar sembahyang. Tiap altar sembahyang memiliki 1 meja dupa, 1 meja panjang serta 1 bilik atau tempat khusus untuk setiap dewa.
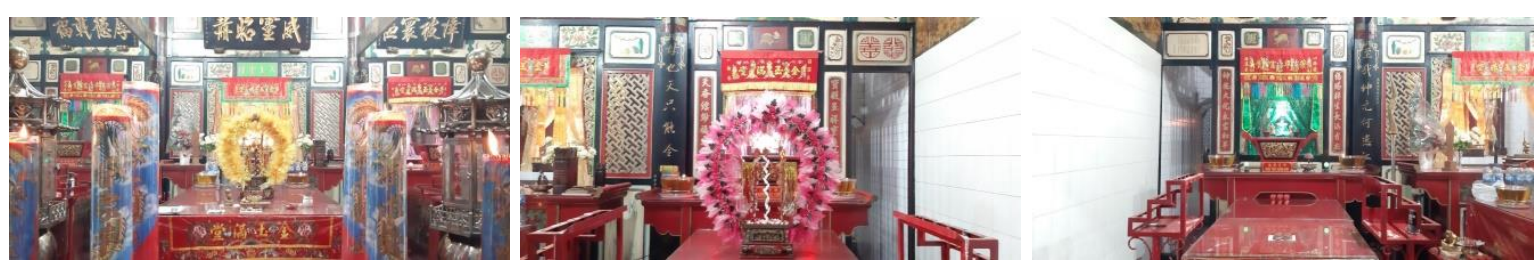

Gambar 4. Altar Sembahyang Lantai 1 (Dari kiri : Altar 1, Altar 2, Altar 3) Sumber : Dokumentasi Penulis (2021)

Altar 1 terdapat patung Tian Shang Sheng Mu yang merupakan tempat bagi tuan rumah (dewa utama). Altar ini berada tepat di tengah klenteng dan merupakan altar sembahyang pertama setelah sembahyang ke Thien (menghadap langit). Kemudian di sebelah kanannya ada altar untuk Guang Ze Zun Wang (Kong Tek Cun Ong). Setelah sembahyang ke altar 1 dan 2, umat akan sembahyang ke altar 3 yakni altar untuk dewa Fu De Zheng Shen (Hok Tek Ceng Sin) 
Tresiyani Mettasari Liesawan ${ }^{1}$, Jesseline Carissa Novita ${ }^{2}$

Analisis Tata Ruang dan Makna Simbolis Ragam Hias Binatang pada Klenteng Tulus Harapan Kita (Thian Huo Kiong) Gorontalo

dan terakhir ke Ne Zha (Lo Tjia). Area sembahyang di lantai 1 terbagi menjadi 2 yakni area depan dan belakang. Pada area belakang terdapat altar sembahyang untuk Guan Yu (Kwang Kong).

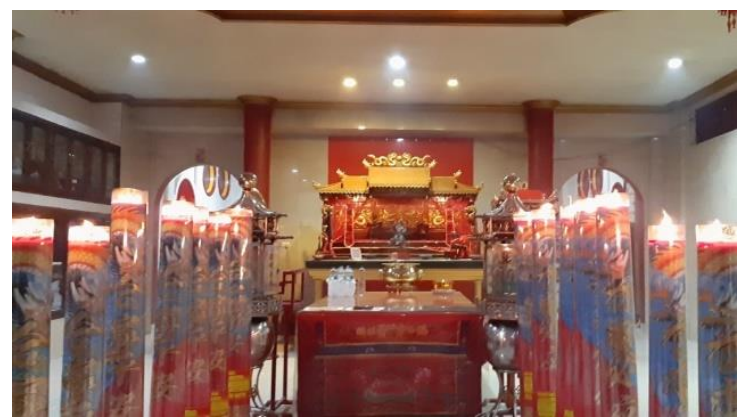

Gambar 5. Altar Sembahyang Lantai 1 (Guan Yu/ Kwang Kong) Sumber : Dokumentasi Penulis (2021)

\section{Lantai 2}

Ruangan di lantai 2 juga terbagi menjadi 2 bagian yakni depan (altar 6) dan belakang (altar 5). Namun, untuk umat sembahyang biasanya hanya menggunakan altar belakang karena altar depan biasanya dikhususkan untuk pengurus kerohanian. Di altar belakang/altar 6 terdapat meja sembahyang untuk Tri Nabi Agung yakni Buddha Gautama, Thai Siang Li Lo Kun, dan Kong $\mathrm{Hu} \mathrm{Cu}$.
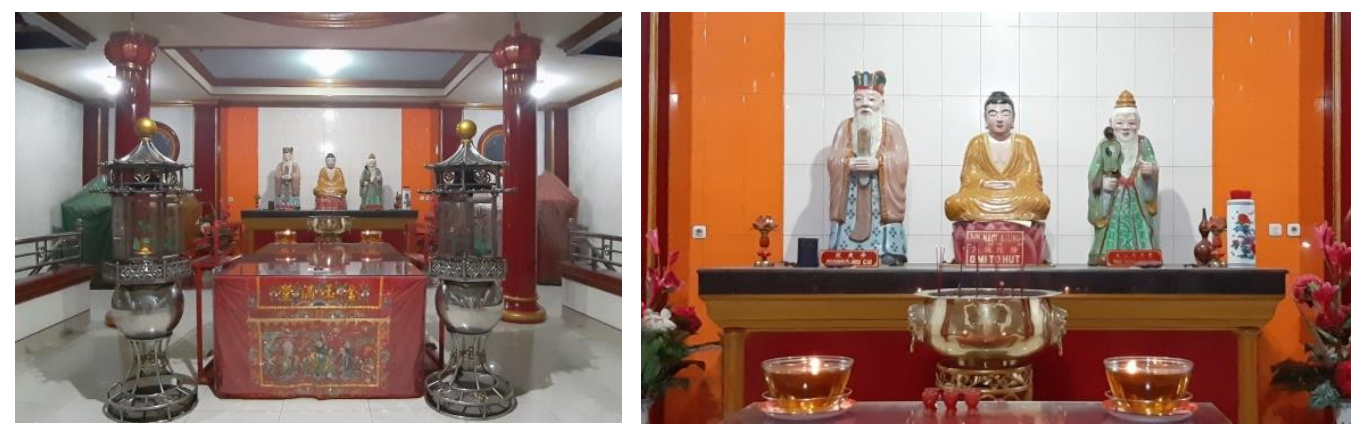

Gambar 6. Altar Sembahyang Lantai 2 (Dari kiri : Kong $\mathrm{Hu} \mathrm{Cu}$, Buddha, Thai Siang Li Lo Kun) Sumber : Dokumentasi Penulis (2021)
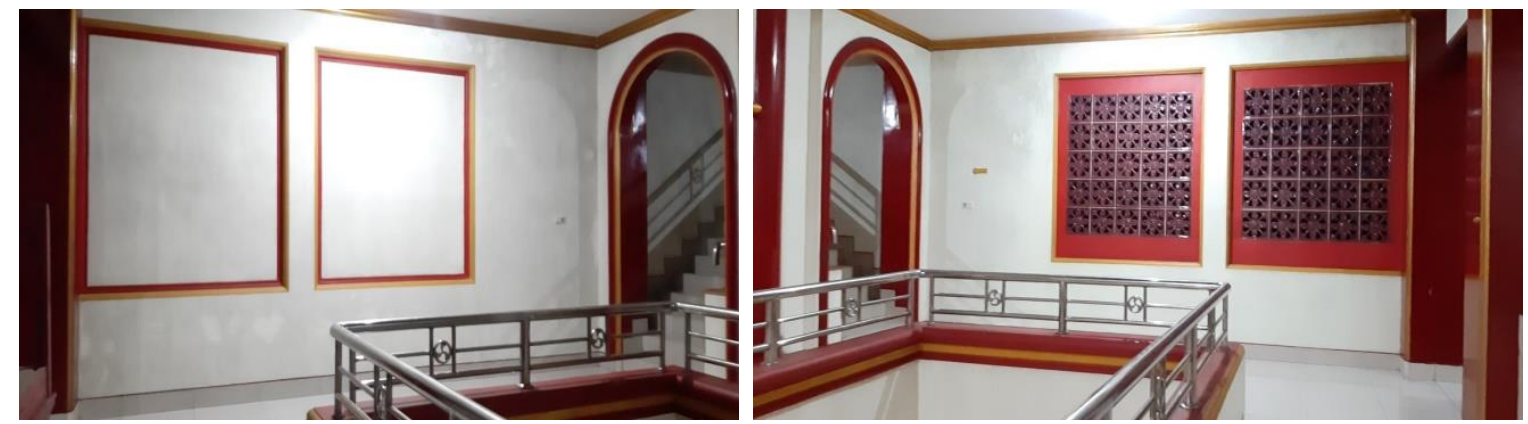

Gambar 7. Area Tangga Menuju Lantai 3

Sumber : Dokumentasi Penulis (2021) 


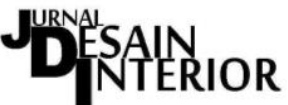

Vol. 6, No. 1, Juni 2021, ISSN 2527 - 2853

\section{Lantai 3}

Di lantai 3 hanya terdapat 1 ruangan dan 1 altar sembahyang yakni altar Kwan Im. Di depan altar terdapat pintu besar yang langsung menuju serambi untuk penghawaan alami. Semua yang ornamen interior pada lantai 2 dan 3 di desain simetris dengan dominan warna merah. Terdapat bukaan pintu besar di samping kanan, kiri dan depan altar untuk mendapatkan penghawaan alami.
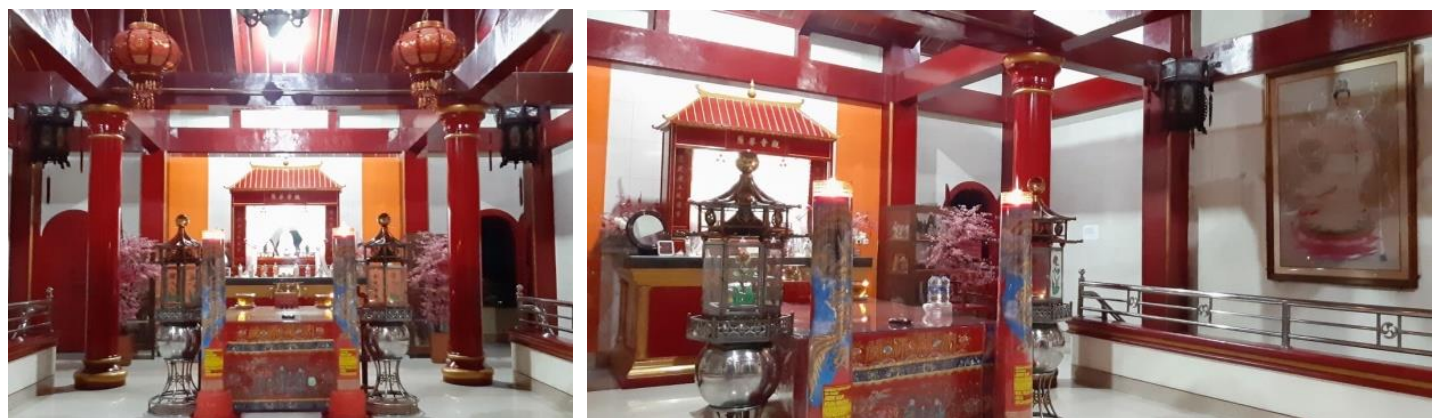

Gambar 8. Altar Sembahyang Lantai 3

Sumber : Dokumentasi Penulis (2021)

\section{Makna Ragam Hias Makhluk Hidup}

Ragam hias yang terdapat di klenteng terdiri dari motif tumbuhan, binatang dan dewadewa yang memiliki makna serta unsur mitologi. Motif ragam hias tumbuhan digambarkan sebagai motif teratai, bunga krisan, pohon bambu dan beberapa bunga lainnya. Motif tumbuhan pada ornamen klenteng dianggap sebagai lambang yang memiliki sifat yang sama dengan kelompok masyarakat Tionghoa yakni memiliki kekuatan alami dan tahan terhadap perubahan iklim. Motif ragam hias binatang yang sering terdapat pada sebuah klenteng. Ornamen binatang biasanya diletakkan di beberapa elemen interior dan yang paling sering diterapkan dalam interior adalah naga, Qilin, burung merak, macan, kelelawar dan juga rusa. Ragam hias dari motif binatang ini dipercaya dapat memberi kekuatan dan segala sifat baik yang ada pada binatang tersebut bisa berpindah dan dimanfaatkan.
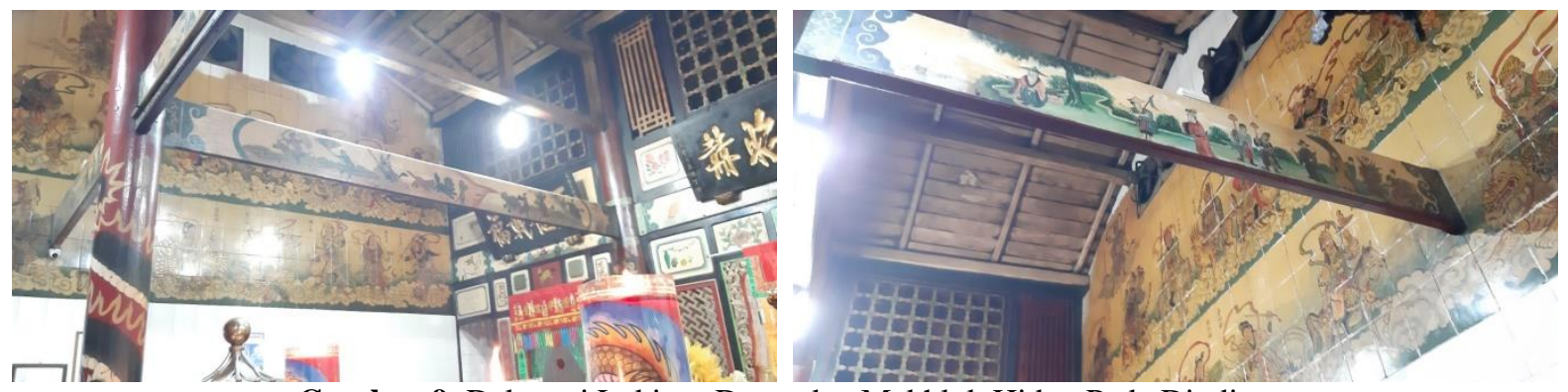

Gambar 9. Dekorasi Lukisan Dewa dan Makhluk Hidup Pada Dinding Sumber : Dokumentasi Penulis (2021) 
Tresiyani Mettasari Liesawan ${ }^{1}$, Jesseline Carissa Novita ${ }^{2}$

Analisis Tata Ruang dan Makna Simbolis Ragam Hias Binatang pada Klenteng Tulus Harapan Kita (Thian Huo Kiong) Gorontalo

Di setiap klenteng selalu menempatkan sepasang naga yang berhadapan untuk berebut mutiara hitam menyala (melambangkan matahari). Naga di atap klenteng didesain untuk mengapit Ho Lo, yaitu buah labu yang telah kering sebagai tempat air. Ho Lo biasanya menjadi bekal para dewa sehingga dianggap memiliki ilmu atau kekuatan gaib untuk menjaga Hong Shui dan menangkal hawa jahat. Pada Klenteng Tulus Harapan Kita (Thian Huo Kiong) Gorontalo ini terdapat ragam hias binatang yang menghiasi interior. Yang paling dominan menghiasi klenteng adalah naga. Selain naga, klenteng ini juga memiliki ragam hias lain seperti singa/Qilin dan macan.
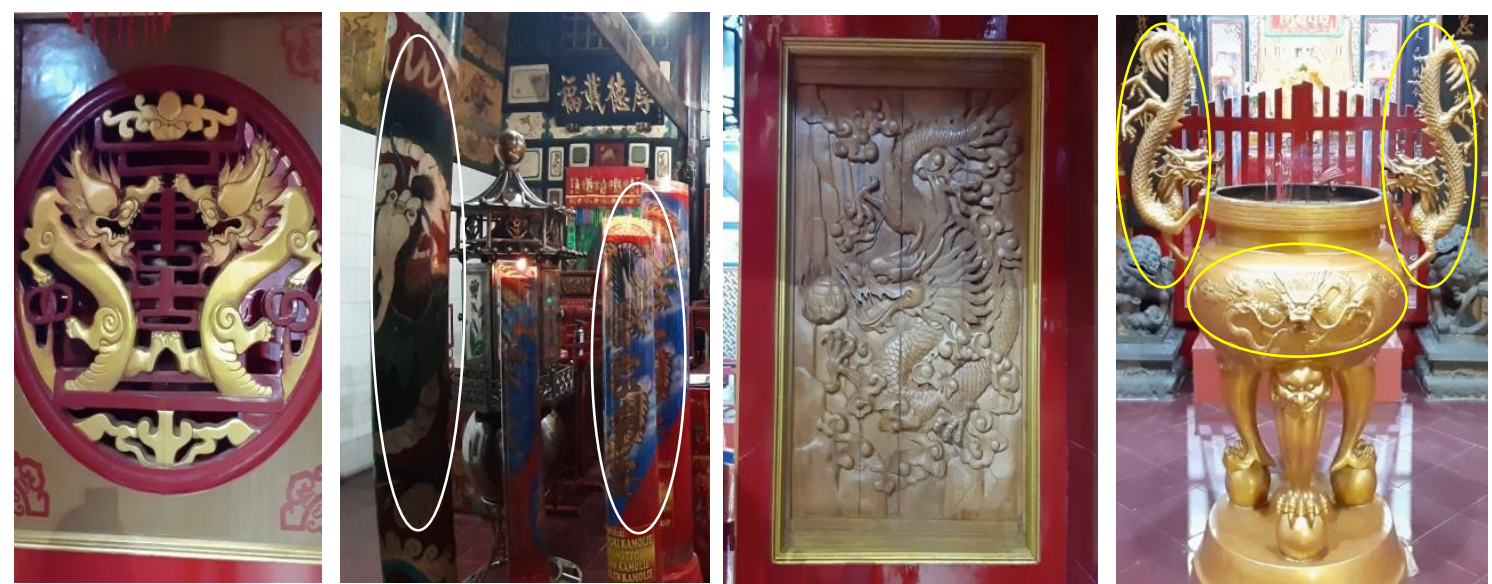

Gambar 10. Ragam Hias Naga Pada Dinding, Kolom, dan Dekorasi

Sumber : Dokumentasi Penulis (2021)

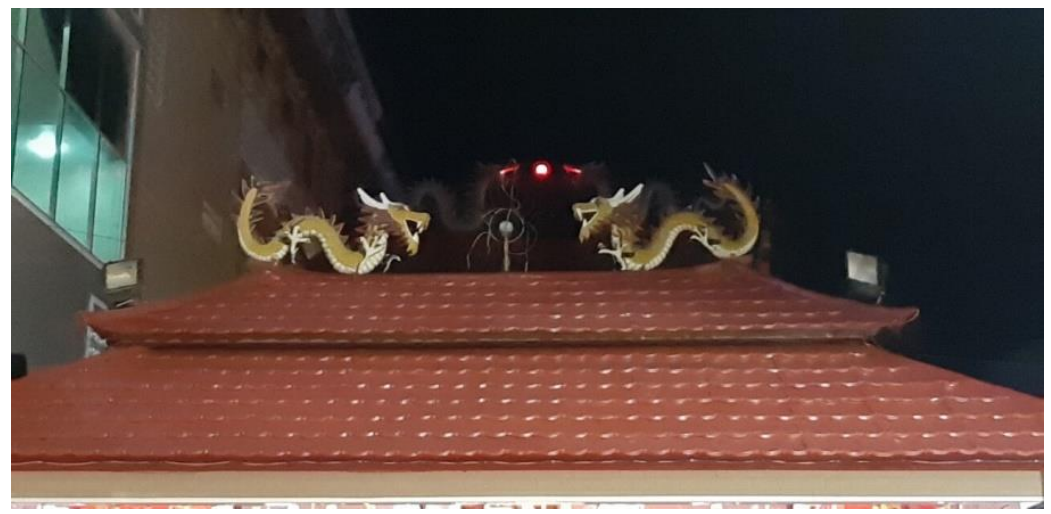

Gambar 11. Ragam Hias Naga Pada Atap Klenteng

Sumber : Dokumentasi Penulis (2021)

Bagi masyarakat Tionghoa, naga adalah hewan yang paling populer dan sering digunakan dalam ragam hias karena dipercaya sangat berkuasa. Penggambaran naga biasanya terbagi menjadi 3 jenis yakni Long, $L i$ dan Jiau. Yang paling banyak digunakan adalah Long yang merupakan makhluk berkepala unta, bermata kelinci, berleher ular, bertanduk kijang, berperut katak dan memiliki cakar seperti harimau (Moedjiono, 2011). Di Klenteng Tulus Harapan Kita, naga digambarkan dalam jenis Long. Ornamen naga pada klenteng ini terdapat pada ornamen dekorasi dinding di pintu masuk, pintu, atap serta kolom bangunan. 


\section{DDEATINRIOR}

Vol. 6, No. 1, Juni 2021, ISSN 2527 - 2853

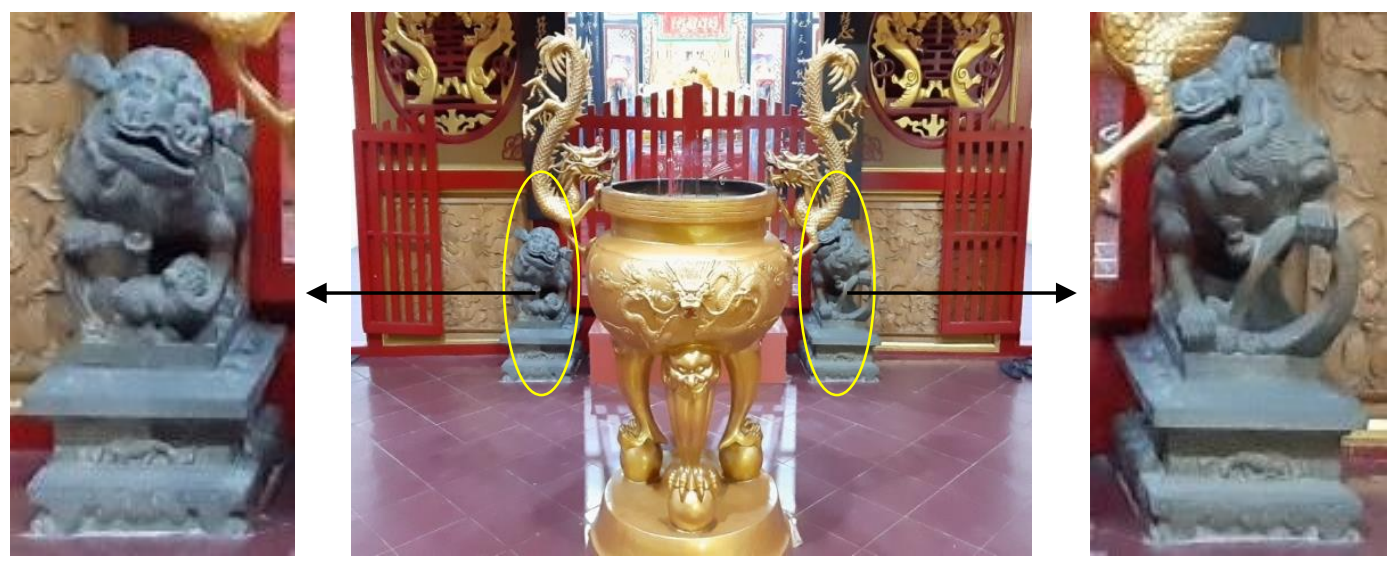

Gambar 12. Qilin Pada Sisi Kanan dan Kiri Pintu Tuan Rumah

Sumber : Dokumentasi Penulis (2021)

Qilin atau Singa merupakan salah satu makhluk mitologi dari Cina. Qilin memiliki banyak deskripsi di antaranya ada yang mengatakan bahwa makhluk ini memiliki campuran bentuk kuda dan seekor naga. Lalu ada yang mengatakan seperti seekor rusa berekor banteng dan bersisik ikan dengan tanduk yang tertutupi oleh rambut singa atau memiliki bagian tubuh dari perpaduan rusa dan seekor rubah dengan tanduk di kepalanya, biasanya dibuat dari batu dan terdiri dari jantan dan betina. Singa melambangkan keadilan dan kejujuran. (Wicaksana Abibawa, 2017). Biasanya Qilin/singa ini sengaja ditempatkan di depan pintu masuk dan saling bersebelahan.

\section{KESIMPULAN}

Dari uraian hasil penelitian di atas, dapat disimpulkan bahwa penataan ruang sebuah klenteng berbeda-beda tergantung masyarakat di sekitar atau pihak yang membuat klenteng. Satu hal yang pasti adalah altar pertama yang berada di tengah merupakan tuan rumah (dewa utama) dari klenteng tersebut. Penentuan dewa utama ini dilakukan oleh masyarakat Tionghoa itu sendiri. Di dalam klenteng terdapat tradisi dan kepercayaan untuk memasuki klenteng harus melewati pintu naga di kanan kemudian keluar di pintu harimau di kiri. Selain itu terdapat ragam hias yang tidak hanya dijadikan pajangan atau dekorasi namun memiliki makna simbolis dari masing-masing ornamen ragam hias. Pesan simbolis yang terdapat pada ornamen inilah yang menjadi alasan pemilihan ragam hias tersebut untuk menghiasi sebuah klenteng. Namun tentu saja hal ini tidak jauh kaitannya dengan tradisi masyarakat setempat yang percaya bahwa penempatan ornamen klenteng bisa mendatangkan hal baik sesuai dengan makna ornamen itu sendiri. Pada Klenteng Tulus Harapan Kita (Thian Huo Kiong) Gorontalo ini dapat disimpulkan banyak mengambil ornamen naga sebagai ornamen pengisi ruang. Hal ini dapat dengan jelas terlihat mulai dari pintu masuk hingga di dalam klenteng terdapat banyak simbol dan ornamen naga pada bangunan.

\section{DAFTAR PUSTAKA}

Damayanti, Siska. (2017). Fungsi dan Makna Relief dan Ornamen Pada Klenteng In Hok Kiong di Bagansiapiapi. Skripsi: Program Studi Sastra Cina, Fakultas Ilmu Budaya, Medan: Universitas Sumatera Utara. 
Tresiyani Mettasari Liesawan ${ }^{1}$, Jesseline Carissa Novita ${ }^{2}$

Analisis Tata Ruang dan Makna Simbolis Ragam Hias Binatang pada Klenteng Tulus Harapan Kita (Thian Huo Kiong) Gorontalo

Hassanuddin. \& Basri, A. (2012). Gorontalo Dalam Dinamika Masa Kolonial. Yogyakarta: Ombak.

Husna, Thobi'atul. (2020). Klenteng Kwang Sing Bio di Kelurahan Karangsari, Kecamatan Tuban, Kabupaten Tuban, Jawa Timur (Sejarah, Struktur dan Fungsi Serta Potensinya Sebagai Sumber Belajar di SMA). Jurnal Candra Sangkala. Vol. 2 No. 2.

Katadata. (2016, 12 13). Indonesia, Populasi Etnis Cina Terbanyak Di Dunia. Retrieved April 1, 2021, from https://databoks.katadata.co.id/datapublish/2016/12/13/indonesiapopulasi-etnis-cina-terbanyak-di-dunia

Kustedja, Sugiri., Sudikno, Antariksa \& Salura, Purnama. (2013). Makna Ikon Naga, Long, Elemen Utama Arsitektur Tradisional Tionghoa. Jurnal Sosioteknologi. Vol. 12 No. 30 Edisi Desember.

Liang, L. (2012). Dari Relasi Upeti Ke Mitra Strategis; 2.000 Tahun Perjalanan Hubungan Tiongkok Indonesia. Jakarta: Kompas.

Moedjiono. (2011). Ragam Hias dan Warna Sebagai Simbol Dalam Arsitektur Cina. Jurnal Modul. Vol. 11 No. 1 Edisi Februari.

Salim, Polniwati. (2011). Ragam Ornamen Atap Klenteng Jin De Yuan Sebagai Salah Satu Aset di Kawasan Kota Tua. Jurnal Humaniora. Vol. 2 No.2 Edisi Oktober.

Surwartono. (2014). Dasar-dasar Metodologi Penelitian. Yogyakarta: Penerbit Andi.

Wicaksana, Abibawa. (2017). Qilin, Makhluk Mitologi China, Dalam Karya Keramik. Tugas Akhir: Program Studi Kriya Seni, Jurusan Kriya, Fakultas Seni Rupa, Yogyakarta: Institute Seni Indonesia.

Yunus, Resmiyati. (2018). Pembauran Etnis Tionghoa Dan Gorontalo Pada Sektor Ekonomi Ditinjau Dalam Perspektif Sejarah Di Kota Gorontalo. Jambura, History and Culture Journal. Vol. 1 No. 1. 